\title{
ANALYTICAL STUDY OF THE POLITICAL STATUS AND ROLE OF WOMEN DURING THE INDIAN INDEPENDENCE MOVEMENT
}

\author{
Dr. Sanjeev.C. Shirpurkar \\ Associate Prof-Dept. of Political-Science, \\ S.K. Porwal Arts \& Science\& Comm College, \\ Kamptee, \\ District-Nagpur (M.S)
}

\begin{abstract}
Like the freedom movement of the other countries of the world, the history of freedom movement in India is rich with equal participation of men and women. Like other countries of third world, our countrymen also had to struggle long and hard to get freedom. In the glorious story of the struggle against the British rule, the names of many brave sons as well as the names of brave ones are also printed in the golden letters in history. As such, during the freedom movement, the role of intellectuals, farmers, lawyers and social reformers has been very important at every level and at every stage of the movement. But keeping in mind the circumstances of that time, it is also very interesting and important to analyze the role of women in this regard. From the Vedic era to the modern era, the role of women has been changing according to the time and circumstances in the various segments.Lopamundra,Ghosha and Apala in Vedic era, Gargi and Maître in post Vedic era, Sheela and Attarika in the Gupta age and in the Mogul era Razia gninfluence in politics was important and extra-ordinary. Similarly, the role of Begum Hazrat Mahal and Jhansi Queen Rani Laxmi Bai during the period of independence struggle especially during 1857 Revolution and later in the Gandhi era, Mrs. Annie Besant, Bhagini Nivedita, Madam Cama,Pandita Ramabai ,Sarojini Naidu,Kamla Nehru, Sucheta Kruplani,Prabhadevi,Vijaya Laxmi Pandit, Mniben Patel and the roles of other such women cannot be ignored.Similarly,the British Education system, increased the means of transport and the social reform movement has increased the political consciousness of women and motivated them to contribute to the National Movement. In spite of all the adverse circumstances such as low educational level and various ban in public life, after tough struggles, women made their unique identity in the history of freedom movement. Gradually, women became involved in social issues, their understanding in this regard increased which changed their thinking. Due to this, women gradually moved forward in the struggle for independence, in the movement of reforms and in the Legislative Councils. Here also the fact cannot be denied that most of the women who led the national movement were highly educated and belonged to the upper middle class.
\end{abstract}

KEY WORDS-National movement, Social reform, Political consciousness, Women's Organization, Gandhi Era, Female suffrage.

\section{REVIEW OF LITERATURE}

Before analyzing the role of women in the freedom movement, we need to know about the status of women in the Vedic,Post-Vedic,Mauryan era,Gupta dynasty, Mughal period, only than we will be able to make a meaningful analysis of the role of women in the Indian Independence movement in the Modern era. As far as the Vedic era is concerned, in this era, women were respected in the society, despite being a patriarchal family,women got enough freedom in their respective fields and their role in the decision process was also very important. "Although the role of women was not equal in politics and administration ,but the place of the women in the society was satisfactory."(1) (Shastri,1952). As far as the post-Vedic era is concerned, it can be said that Gargi and Maitriyi are considered to be great philosophers of this age. The conversation between Maitriyi and her husband Yajnavalkya towards them is a considerable question of the Upanishads, but in this era, it is known by Manu-Smruti, that Manu was not an advocate of equal rights for men and women. According to him - "In childhood, the women lives under the patronage of her father, in young age under her husband and in the old age under the tutelage of her son. So, only Swami-Bhakti can be expected 
from them, but Manu also belives that where there is respect for women, there will always be prosperity." (2) (Altekar,1956). According to Megasthenes " the practice of multiple marriages was prevalent in the Mauryan era, Indians used to marry many women, women could remarry like man". (3) (Mc Crindle). As far as the Gupta era is concerned, in this age also, women generally had a respectable place in the society, "usually girls used to be proficient in singing, dancing and household work. Women like Sheela and Attarika were famous in the field of poetry and writing". (4) (Luniya). If we are talking about the Mughal period, the status of women in this era was not generally satisfactory and their reputation was slowly declining. In this era, child marriage and sati had come into existence and the women was considered to be the object of enjoyment. Similarly, under the British rule in the modern era ,some women changed the course of history by influencing politics and governance.

\section{OBJECTIVES OF THE RESEARCH PAPER}

This research paper mainly focuses on 2 points-

1) Depicting the social and political status of women in the ancient,middle and modern era.

2) Explaining the role of women in freedom struggle.

\section{RESEARCH METHODOLOGY}

This research paper mainly based on secondary sources and historical facts. Historical, descriptive and analytical methods have been used to analyze historical facts and events.

\section{DISCUSSION ON RESEARCH PAPER}

History is a witness to the fact that the countries in which women and man have played a strong and meaningful role in the political, social, economic and administrative system, the nation has moved ahead of other countries in the race of progress. Before analyzing the role of women in India's national movement, it is very important to know what the role of women was in the social, political and economic system of ancient times and middle ages. Here we will analyze the status and role of women in different eras with reference to the title of research.

Dignified status of women in Vedic age -

In this era, women had a high status in society. Women and men, participated equally in religious festivals, they also had equal rights related to education and many women were famous as teacher, philosopher, skilled speaker and famous poetess but women did not have succession in property and their role in politics and administration was negligible. "In matters like education, religion and marriage, women could take self-decisions and they had high social status. (5) Overall, we have to agree here that the condition of women in various areas of life in the Vedic period society was quite satisfactory.

Partial change in conditions in the post-Vedic Era -

Even in this era, the archaic tradition prevalent in respect of women remained unchanged. She used to be completely independent in the field of education. She could study philosophy. Gargi and Maitri were considered great philosophers of the Post-Vedic period. It is written in Manusmriti that women used to get patronage of father, husband and son and he further write that where there is respect for women, there will always be prosperity.

Status of Women in Gupta and Mauryan Era-

The condition of women was not very good in the Mauryan period, according to Megasthenes, Indians used to marry many women, that is, the practice of multiple marriages existed in the Mauryan era, women could remarry like men.

Similarly, in the Gupta era, women had a respectable place in the society in general, participation of women in social and religious work was equal to men. Generally, the girls were proficient in singing, dancing and housework. Women like Sheela and Attarika were famous in the field of poetry and writing.it can be said that women had a lot of freedom in the field of education and music.

The Prestige of Women Declines during the Mughal Period-

The condition of women in this age cannot be considered satisfactory. Due to the influence of Muslim culture, in this era, the child marriage and curtain practice came in to existence and the women was considered as an object of enjoyment. Incidents like multiple marriages, sati and practice of Zohar also the result of this era. Despite all these obstacles, women had established their identity in politics and administration, Among these women Shah Turkan,Raziya Begum,Mahim Begum,Khanjada Begum,Harram Begum had gained fame due to their administrative

capability.Similarly,Noorjahan,Jahanaara,Roushanaar a and Mumtaz's influence in politics was significant and extra-ordinary. We have to accept that the most of women belonging to the royal family was active in the politics and administration whereas the participation of common women is not mentioned. It is clear from this deliberation that during this period only such women accepted the role in politics and administration, who were not afraid of exploitation of the rulers, although the percentage of such women remained very low.

Struggle and Participation of Women in Modern Age-

In order to destroy the British rule in the Modern era, men as well as women registered active participation. In this era too, many women not only 
influenced politics and governance but also changed the stream of verna history.

Revolution of 1857 and Women-

Begum Hazrat Mahal can be named among the women who became the inspiration for the freedom struggle of 1857,against the British rule,who not only made her son Nirjis Kadar on the throne of Avadh but also fight against British rule.In this episode, the name of Rani Laxmibai of Jhansi is also considered to be pioneer because she took the throne of Jhansi after the death of her husband Gangadhar Rao and took revolutionary political decisions and fought against the Britishers till death.Similarly,Teja Bai,wife of king Govind Rao,the rular of Jalaun,also opposed the Britishers because they had fixed their pension.The British had kept her in jail for about 12 years.

$19^{\text {th }}$ Century Reform Movement and the Role of Women-

After the revolution of 1857 , many changes were seen in the Indian social system. Elements like,westernization ,Modernization,Social reform movements and National awakening brought unprecedented awareness among Indian women in the $19^{\text {th }}$ and $20^{\text {th }}$ centuries. Similarly,the social reform movements tried to improve the misery of the women. These reforms movements also contributed a lot in creating female consciousness. The British Education system and means of transport also reflected positive impact on social and political consciousness. "Maharashtra and Bengal were the largest number of women who participated extensively in the various reform movement organized during the freedom movement. The entry of women into the field of social reform was like breaking away from the past". (6)

Establishment of Congress and women Awakening -

We can say that since the establishment of the congress in 1885 , the systematic path of female consciousness got paved. In 1900, for the first time,Mrs.Ganguli gave her address from the congress platform as a female speaker.Similarly,in 1905,the women were strongly opposed to the declaration of dissolution by Lord Curzon.Gradually,women were not limited to the congress session only; they started opposing the policies of the government through agitations on the street.Mrs.Sarojini Bose and Mrs. Annie Besant led the protest against Britishers. "Mrs.Annie Besant wanted to bring home rule to India in the same way as the other colonies of Britain, which is why she also started the Home Rule Movement". (7)

Although, in the last decades of the $19^{\text {th }}$ century, educational reform and social reform related activities gave birth to a new group of intellectual citizens, but initially the number of women in this group was very less. Even through newspapers and magzines, the level of educational and political consciousness gradually improved. Gradually women started separating from male organizations and also started their women's organizations.Saraladevi Chaudhurani created an organization called "Bharat Stree Mahamandal"'in 1910 and through this organization he linked Hindu revival with political opposition.Important women organizations that were established during the freedom struggle were known as a "Women's Indian Association(WIA), The National Council for Women in India(NCWI) and The All India Women's Conference(AIWC).All these organizations played a major role in articulating women's issue.WIA was founded in 1917 and is considered a representative organization of women of all clasess,all cultures and all religions.Similarly,NCWI was established in 1925 as a National branch of the International Council of Women and the main objective of this institution was to submit memorandum to the appropriate authorities regarding various issues related to women. The AIWC was founded in 1927 and this organization also presented the socio-economic and political issues related to women with pride. It is also important to mention here the story "Sultanas Dreem"composed by Rukaiya Sakhavat Hussain in 1908 because the reader of this story got the idea of self government system of women through the story. Political Participation of Women in Various Movements Conducted in Gandhi Era-

Mahatma Gandhi believed that women's participation can prove to be very important for the reconstruction of society, so under his leadership, a lot of efforts was made to create an environment towards establishing political equality. Among the women who played a prominent role in the movements in various activities related to the national independent movement in the Gandhi era were Madame Cama, Bhagini Nivedita, Annie Besant, Pandita Ramabai, Sarojini Naidu, Kamala Nehru, Maniben Patel, Vijay Laxmi Pandit, Sucheta kripalani, Prabhadevi and many much women. These women gave paramount importance to their duties towards the nation, without worrying about their home, family and children. During this period, there were some women who took the help of revolutionary means to build a new India,among such women - Durga Bhabhi,Satyavati devi, Khurshid Bahan, Jadi Rani Jutshi can be named prominently. In the same way,well-known women like Pritilata Vaddedar,Usha Mehta,Durgabai Deshmukh and Ammu Swaminathan were also part of this national movement who worked for the benefit of the country through active social service.Gandhiji used to say that "if women develop a high level of courage,than Indian womens are natural leaders"(8)

Similarly, during the Non-Co-operation Movement under the leadership of Gandhiji in 1920, some independent women's organization like Rashtriya Mahila Sangh were empowered with the district congress committees. As the area of this 
movement became wider, the women of this country continued to join this movement. During this movement,there was tremendous unity among HinduMuslim women. In Ahmedabad,Amma,the mother of Ali brothers,gave a speech in front of 6000 women and urged women to accompany men in picketing and demonstration organized against British rule. Similarly, in Andhra Pradesh, an example can be given of the stunning Durgabai, who collected more than 1000 Devadasi and performed the important work of connecting Hindu Widows to the national movement. All these women were ideal freedom fighters for Gandhiji. (9)

Similarly,during the Civil Disobedience Movement organized under the leadership of Gandhiji in the 1930s, various programs such as boycott movements, Padyatras and Prabhat fairies etc.were also directed and guided by women.During this movement, a group of patriotic women was being prepared that did not back down from making their arrests. In the same way, some women joined the revolutionary organizations and they supported the revolutionaries even till the killing of the British Officers. Sarojini Naidu,Muthulakshmi Reddy,Margaret Cousin and Kamaladevi Chattopadhyay may be named among some of the prominent women who were arrested in the 1930s. That is to say that,liberal households and conservative families, from cities to villages,virgins and various married women,young and old ladies,played an important role in the struggle against the British rule.(10)

Similarly, women participated actively in the Quit-India movement of 1942 under Gandhiji's leadership. Women not only boycotted foreign goods, they led the Prabhat Pheri and picketing at liquor shops and they made all such efforts that would force the British to leave India. During this movement ,the role of women like Usha Mehta and Aruna Asaf Ali is considered very important in organizing women and motivating them for active participation in every phase of the movement. Sarojini Naidu was also arrested during this movement for organizing active protests against the British rule.

Overall, it is very important to make special mention of Sarojini Naidu and Aruna Asaf Ali among the women who fought against the British Empire in the Gandhi era. Mrs.Sarijini Naidu, by virtue of her talent, had acquired a very important place in that time of Indian politics. She also presided over the annual congress session held in 1925 in Kanpur.Similarly,she also chaired the "East African Indian Congress" held in South Africa in 1929.The British government awarded him a title like "Kesare-Hind" to commemorate her co-operation in various levels in combating a severe epidemic like the "Plague". We also need to mention here that her role in the "Dharsana Salt Satyagraha"of Gujrat in 1930 and in the "Round Table Conference" held in 1931 was very much appreciated. She had to travel to jail with Gandhiji during the "Civil Disobedience Movement" and similarly she was arrested during the "Quit India Movement". She was entrusted with the responsibility of the post of Governor of the United Provinces of Agra and Avadh" from 1947 to 1949 in independent India.

In the same way, Aruna Asaf Ali also had a very respectable position within the Congress and outside of the Congress. In 1932, she was kept in Tihar Jail where she also went on hunger strike to protest against discrimination from political prisoners.During the "Quit India Movement "in 1942, she also hoisted the flag of the Indian National congress at the "Gowalia Tank Ground" in Mumbai. She also got the distinction of being the first Lady Mayor of Delhi in independent India in 1958. She was eventually posthumously awarded India's highest honor, that is, the "Bharat Ratna"in 1997.

Compared to Western countries,Indian women got the franchise without any special struggle.Frist of all, in 1929,women started contesting for the central and provincial administrative institutions.In 1937, under the provincial polity,50 women were also elected to various provincial assemblies.Similarly, 6 women were also given ministerial posts in provincial ministry.

In the same way, the role of women can also be considered very important in the formulation of Indian Constitution because women got adequate representation in the constituent Assembly. The role of Leela Ray,Sarojini Naidu,Ammu Swaminathan,Malti Choudhary,Puenima Banerjee,Rajkumari Amrit Kaur,Hansa Mehta,Sucheta Kriplani,Durgabai,Renuka Rai,Kamala Choudhari is considered to be very important among the constitutional women.Finally, the Indian constitution, which came into force from $26^{\text {th }}$,January1950, accepted full participation of women in Indian politics by giving them equal voting rights to all men and women without any gender distinction.

\section{CONCLUSION}

Overall, it can be said that the secret of the success of the Indian National Movement is hidden in the equal contribution of both men and women. After getting cast in the mold of British education system, women not only got involved with social reform movements but also trended the establishment of women's organization. Under the banner of these reform movements and through women's organizations, awareness and political consciousness was created among the masses incliding women. This awareness and consciousness gradually grew, which paved the way for women to occupy political positions and active political participations. Despite the limitations of social and political life, such an 
example of active contribution of women at various stages of national movement and at various levels is rarely seen in world history. Although it is true that most of the women associated with the national movement were part of highly educated and elite families. But apart from these women, the contribution of thousands of such women also cannot be forgotten whose names are not recorded in the pages of history, but who dedicated their everything by staying behind the curtain for the freedom movement.The seeds of the participation of women during the freedom movement were the result of the fact that ,today there is hardly any area of public life left in independent India where women have not made their dignified presence.

\section{REFERENCES}

1) Shastri, Radha Kumud (1952) "Woman in Vedic Age”, Bhartiya Vidya Bhavan, Mumbai, P-6.

2) Altekar, A.S (1956) "The Position of Woman in Hindu Civilization", Motilal Banarsidas, Mumbai, P-338.

3) Crindle Mc," Magasthenes", P-34.

4) Lumia, B.N (2001), "Prachin Bharat Ka Rajnitik Avam Sanskrutik Itihas" Kamal Prakashan, Indore, P-313. (Hindi-Addition)

5) Shastri, Radha Kumud, (1952), "Woman in Vedic Age”, Bhartiya Vidya Bhavan, Mumbai, P-6.

6) Kaushambi, Meera, (2007)," Crossing Thresholds: Feminist Essays in Social History, Permanent Black, Delhi,2007.

7) Report of the "Desh Sevika Sangh1931-34", Young India, April 1930, P-130-131.

8) Khullar, K.K, "Role of Women in National Movement", Employment News, August 11-17, p-1-5.

9) Atwal, Jyoti- "Revisiting Premchand: Shivrani Devi on Companionship, Reformism and Nation" Economic and Political Weekly, Addition-42, Vol-8, May 5-11,2007, P-1631-7.

10) Forbse, Geraldine: women in Colonial India: Essays in Politics, In Medicine and Historiography "A Politics of Respectability: Indian Women and Indian National Congress", Delhi, Chronical Books, 2005, P-11. 